\title{
Mass dynamics of the spleen and other organs in geese: measures of immune relationships to helminths?
}

\author{
Dave Shutler, Ray T. Alisauskas, and J. Dan McLaughlin
}

\begin{abstract}
The spleen is an important organ of avian immune systems. We examined whether helminth loads were related to spleen mass in the lesser snow goose, Chen caerulescens caerulescens. On 27 collecting occasions, 744 geese were obtained at 13 different locations in a south-north gradient in midcontinental North America. The masses of the spleen, caecum, small intestine, large intestine, pancreas, heart, and crop of all geese were determined, and intestinal and caecal helminths were counted. Seventy-eight percent of geese harbored at least one helminth species. For analyses, helminths were grouped as cestodes (26\% prevalence), trematodes (19\% prevalence), and nematodes (70\% prevalence). After sample location and time, host age, host sex, and host body size were controlled for in a multivariate analysis of covariance, nematodes were the only helminth group associated with variation in organ masses. Greater nematode loads were weakly associated with lower spleen, higher caecum, lower large intestine, and lower heart masses. When uninfected individuals were excluded from the analysis, greater nematode loads were no longer associated with variation in spleen size but were associated with higher crop mass, and greater cestode loads were associated with higher heart mass. In neither of these analyses were any other cestode-organ or trematode-organ associations significant. Geese carrying two or more helminth groups had lower spleen masses than did geese infected with no or one helminth group. When we interchanged response and explanatory variables from the preceding analyses and retained the same covariates, the same organ mass - helminth associations tended to remain significant. Nonetheless, the small variation in helminth loads explained by variation in spleen mass (or vice versa) provided only weak support for the hypothesis that intraspecifically, wild individuals with lower investment in immunity are more susceptible to nematode infections.
\end{abstract}

Résumé : La rate joue un rôle important dans le système immunitaire des oiseaux. Nous avons examiné si les fardeaux de parasites étaient reliés à la masse de la rate chez la Petite Oie blanche, Chen caerulescens caerulescens. Sept cent quarante-quatre oies ont été obtenues au cours de 27 échantillonnages à 13 localités le long d'un gradient sud-nord au milieu du continent nord-américain. La rate, le caecum, le petit intestin, le gros intestin, le pancréas, le coeur et le jabot ont été pesés, et les helminthes intestinaux et caecaux ont été comptés chez tous les oiseaux. Soixante-dix-huit pour-cent des oies étaient porteuses d'au moins une espèce d'helminthe. Les groupes d'helminthes, cestodes (prévalence de 26\%), trématodes (prévalence de 19\%) et nématodes (prévalence de 70\%), ont été analysés. Après transformation des données pour tenir compte de la localité et du moment de l'échantillonnage, de même que de l'âge, du sexe et de la taille de l'hôte dans une analyse multidimensionnelle de covariance, les nématodes se sont avérés le seul groupe associé à la variation de la masse des organes. Les fardeaux plus grands de nématodes étaient faiblement associés à une rate de masse plus faible, un caecum de masse plus grande, un gros intestin de masse plus faible et un coeur de masse plus faible. En soustrayant les individus non parasités de l'analyse, les fardeaux de parasites les plus importants n'étaient plus associés à la variation de la masse de la rate, mais plutôt à une jabot plus lourd et les fardeaux les plus importants de cestodes étaient associés à une masse cardiaque plus élevée. Dans les deux analyses précédentes, ni l'une ni l'autre des associations cestodes-organe et trématodes-organe n'était significative. Les oies porteuses de deux groupes d'helminthes ou plus avaient la rate moins lourde que les oies non infectées ou porteuses d'un seul groupe d'helminthes. En interchangeant les variables explicatives et les variables répondantes des analyses précédentes tout en retenant les covariables, les mêmes associations masse-helminthes tendaient à rester significatives. Néanmoins, la faible variation des fardeaux de parasites expliquée par la variation de la masse de la rate (ou vice

Received March 17, 1998. Accepted November 6, 1998.

D. Shutler ${ }^{1}$ and R.T. Alisauskas. Canadian Wildlife Service, Prairie and Northern Wildlife Research Centre, 115 Perimeter Road, Saskatoon, SK S7N 0X4, Canada, and Department of Biology, University of Saskatchewan, 112 Science Place, Saskatoon, SK S7N 5E2, Canada.

J.D. McLaughlin. Department of Biology, Concordia University, 1455 de Maisonneuve Boulevard West, Montreal, QC H3G 1M8, Canada.

${ }^{1}$ Author to whom all correspondence should be sent at the following address: Biology Department, Acadia University, Wolfville, NS B0P 1X0, Canada (e-mail: dave.shutler@acadiau.ca). 
versa) n'appuie que faiblement l'hypothèse selon laquelle, au sein d'une espèce, les individus en nature à faible investissement immunitaire sont plus sensibles aux infections de nématodes.

[Traduit par la Rédaction]

\section{Introduction}

Parasites can impose significant fitness costs on hosts (Anderson and May 1979; Møller et al. 1990). Such costs can arise indirectly if parasites compete for nutrients, thereby slowing the host's growth or reducing its stamina (Seebeck et al. 1971; Batt 1980; Schall et al. 1982; Howard and Minchella 1990; Crompton 1991; Goater et al. 1993; Richner et al. 1993), or directly if they cause tissue damage or affect behaviour (Holmes and Zohar 1990; Thompson 1990). Both indirect and direct parasite effects can increase a host's susceptibility to predators or otherwise reduce its survival (Schall et al. 1982; Temple 1987; Hudson et al. 1992; Spalding et al. 1994; Brown et al. 1995). Regardless of how costs are imposed, a logical prediction is that more severe parasitism will be associated with greater antiparasite investment by hosts. Tests of this prediction should be simplified if there was an antiparasite currency common to different kinds of parasitism and if that currency applied across different host taxa. If the immune system responds according to the relative costs of specific parasites, indices of investment in immunity may provide such a currency. Herein we analyze intraspecific variation in one organ of immunity, the spleen, relative to helminth load in wild lesser snow geese, Chen caerulescens caerulescens.

The immune system is an essential aspect of antiparasite investment. A major organ of immunity is the spleen (Glick 1986; John 1994a, 1994b), and splenomegaly is one symptom of a variety of parasitic diseases (Vincent and Ash 1978; Ali and Behnke 1985; Garside et al. 1989; Watkins et al. 1991; Giacomo et al. 1997). Moreover, the degree of splenomegaly can correlate with the intensity of infection (Ali and Behnke 1985). Hence, John (1994a, 1994b, 1995) and coworkers (Harvey et al. 1991) proposed that spleen mass serves as an index of antiparasite investment. Relative to those of mammals, birds' spleens have less mass associated with oxygen transport; consequently, a greater proportion of avian than of mammalian spleen mass is immune-system-related (John 1994a). For birds, there is both intra- and inter-specific evidence supporting John et al.'s proposal; infections of the blood parasite Leucocytozoon simondi can cause 10- to 20fold enlargement of duckling spleens (Fallis et al. 1951), and enlarged spleens are found in avian taxa that have heavier average parasite loads (Harvey et al. 1991; John 1994b, 1995). Thus, the avian spleen has promise as an index of antiparasite investment, both intra- and inter-specifically. However, parasites may simultaneously cause enlargement of many organs (Fallis et al. 1951), and over evolutionary time, organ masses tend to covary (Konarzewski and Diamond 1995). Hence, the utility of the spleen as an index of immune response requires careful assessment.

Independent of helminth loads, seasonal changes in organ masses can be related to breeding, diet, migration, etc. (Kehoe and Ankney 1985; John 1994a). If helminth loads respond similarly to any of these factors (e.g., because specific diets contain different sets of parasites; Drobney et al.
1983), this could lead to spurious correlations between organ masses and helminth load. One control employed against these spurious results is analysis of specimens collected within brief intervals from one geographic location. Another control is to compare relations between helminth load and immune- versus non-immune-system organs. Parasites can affect many organs simultaneously (Fallis et al. 1951; J. Behnke, personal communication), so the choice of appropriate control organs is problematic. Nonetheless, if the spleen is among the most important of immune-system organs, correlations between spleen mass and helminth load should be stronger and more consistent than for other organs (also see John 1995).

If variation in organ masses is a consequence of parasite load (e.g., Fallis et al. 1951), more intense infections should be associated with larger organs. If, on the other hand, less investment in immunity causes increased susceptibility to parasites, more intense infections should be associated with smaller immune-system organs. The former outcome would support the hypothesis of a short-term response. The latter outcome would support the hypothesis of a long-term (phylogenetic) response and indicate that genetically or nutritionally fitter birds are able to maintain larger organs to fight infections; arguments similar to these have been raised regarding tests of the costs of reproduction (Reznick 1985).

We measured organ masses and assessed helminth loads in 744 snow geese, Chen caerulescens caerulescens. Based on the spleen's immune function and on interspecific comparisons (Harvey et al. 1991; John 1995), we predicted that the correlation between spleen mass and helminth load would be the strongest. Although they have no known immune function, the intestines and caecum of the host may become inflamed as a result of direct contact with helminths, or these organs may increase in length to compensate for nutrient loss to the helminths (Eckert 1991). We predicted correlations of intermediate strength between helminth load and the masses of the small intestine, large intestine, and caecum. The pancreas is also not known to have an immune function, so we predicted that there would be no correlation between helminth load and pancreas mass. The heart is not directly associated with immunity, but cardiac output might be indirectly affected by helminth-induced stress (also see Barnard et al. 1996; Smith et al. 1996), leading to predictions of an intermediate-strength correlation between heart mass and helminth load. Finally, the crop generally carries no helminths and has no known immune function, so we predicted that there would be no correlation between crop mass and helminth load.

\section{Materials and methods}

Geese were collected on 27 separate occasions between 9 January and 21 May 1983 for assessment of helminth load. Collection sites included 13 locations in Louisiana, Texas, Oklahoma, Iowa, Kansas, South Dakota, North Dakota, southern Manitoba, and northern Ontario (each occasion is referred to hereafter as a sample). The Louisiana and Texas samples were entirely wintering birds, the Oklahoma, Iowa, and Kansas samples included a mixture 
Table 1. Sample parameters of organ masses (g) and helminth loads (number of individuals) of lesser snow geese.

\begin{tabular}{lrrrr}
\hline & Mean & SD & Min. & Max. \\
\hline Organ & & & & \\
Spleen & 0.7 & 0.6 & 0.1 & 8.0 \\
Caecum & 10.6 & 6.4 & 2.7 & 99.0 \\
Small intestine & 55.4 & 16.3 & 21.3 & 169.1 \\
Large intestine & 8.0 & 1.9 & 3.9 & 18.7 \\
Pancreas & 6.3 & 1.8 & 0.6 & 17.7 \\
Heart & 17.7 & 2.8 & 9.1 & 29.2 \\
Crop & 19.6 & 3.5 & 10.6 & 33.1 \\
Helminth & & & & \\
Cestodes & 0.98 & 3.47 & 0 & 48 \\
Trematodes & 0.52 & 2.31 & 0 & 48 \\
Nematodes & 26.2 & 49.8 & 0 & 380 \\
\hline
\end{tabular}

of migrants from the south and wintering birds, and the remaining samples included only migrants. Precise site coordinates are provided in Alisauskas (1988). Samples were frozen, usually within $24 \mathrm{~h}$, until dissection. Dissections involved systematic measurement of focal and other organs as part of a larger study (e.g., Alisauskas 1988; Alisauksas et al. 1988; Alisauskas and Ankney 1992; Alisauskas and Hobson 1993). Before dissection, geese were allowed to thaw for 24-48 h. A central incision was made from the cloaca to the head, and the skull was exposed. Where necessary, muscles were excised so that internal structures could be measured. Ten external and internal structural measures were taken to the nearest $0.1 \mathrm{~mm}$ (culmen, wing chord, tarsus length, keel length, body length, skull length, skull width, skull height, bill height, and bill width). Organs were removed, washed, scraped empty of their contents (which were placed in plastic bags and frozen), and weighed to the nearest $0.1 \mathrm{~g}$. Age (based on the size of the bursa of Fabricius) and sex (based on external criteria and gonads) were also determined. Frozen gut contents were sent to J.D. McLaughlin, who identified and enumerated helminths. Following John (1995), helminths were grouped into cestodes, trematodes, and nematodes.

To test whether variation in organ masses was related to helminth load we used multivariate analysis of covariance (MANCOVA). The first MANCOVA had the seven organ masses as simultaneous response variables and cestode, trematode, and nematode loads as explanatory variables. Organ masses may be related to body size. To derive an index of body size, principal components analysis was used on the correlation matrix of the 10 body measures. Original metric variable loadings were similar on the first principal component (size) and explained 52\% of variation in body measures. Parasite loads can also vary by host sex (Alexander and Stimson 1988; Bundy 1988; Zuk 1990; Poulin 1996; Schalk and Forbes 1997; McCurdy et al. 1998), exposure history (including host age) (Weatherhead and Bennett 1991, 1992), and season and (or) location (Bennett et al. 1974; Shutler et al. 1995, 1996). Sample, age, sex, and size were covariates in the MANCOVA.

The second MANCOVA tested whether variation in organ masses was related to the number of helminth groups (number of groups) carried by a host. We classified individuals according to whether they had infections of zero, one, or more than one helminth group(s). In this case, the model had the seven organ masses as simultaneous response variables, number of groups as the explanatory variable, and the same covariates as for the first MANCOVA.

The third MANCOVA tested whether helminth loads were a consequence of investment in organ masses. This model had the three helminth groups as simultaneous response variables, the seven organ masses as explanatory variables, and the same covariates as for the preceding MANCOVAs.
The fourth analysis (ANCOVA) had a single response variable, number of groups, and the same explanatory variables and covariates as the third MANCOVA.

These analyses are not independent (Rice 1989), so we expected that any nonspurious associations would be consistent among analyses. Analyses were performed with a personal computer version of SAS (SAS Institute Inc. 1990). Organ masses and helminth loads were log-transformed before analysis (normality was assessed with Wilks-Shapiro tests). Although deviations from normality remained after log-transformation of helminth loads, the results of parametric analyses were comparable when parasitism was treated as a categorical variable (infected or uninfected). Moreover, we judged that our statistical approach would be robust for our large sample of geese. Nonetheless, because deviations from normality arose when uninfected individuals were included, we also repeated applicable analyses with these individuals excluded.

\section{Results}

Of the 744 geese examined, 85\% were adults and 50\% were female. Organ-mass and infection parameters are summarized in Table 1. Fourteen helminth taxa were identified: $26 \%$ of geese carried cestodes (Sobolevicanthus gracilis, Drepanidotaenia lanceolata, D. barrowensis), $19 \%$ carried trematodes (Echinostoma trivolvus), $70 \%$ carried nematodes (Trichostrongylus tenuis, Heterakis dispar, and Capillaria anatis), and $78 \%$ carried at least one helminth species. Heterakis dispar and T. tenuis both had prevalences of about $50 \%$; other taxa had prevalences below $17 \%$. Prior to analyses, the few individuals with a large spleen appeared to have lower helminth loads (Fig. 1).

The first MANCOVA was done using all geese and was repeated using infected individuals only. Both of these analyses revealed significant variation in organ masses among samples, by age, by sex, relative to size, and relative to intensity of nematode infections (Table 2). We analyzed how these effects were distributed among organs using ANCOVAs (Hatcher and Stepanski 1994). Adults had relatively heavier crops than juveniles (when uninfected individuals were included) (Table 2). Females' organs were relatively lighter than those of males, except that females' caecae were heavier. Larger individuals also had heavier organs (Table 2).

Based on ANCOVAs for the first analysis, greater cestode loads were significantly associated only with higher heart mass and only when uninfected individuals were excluded from analysis (Table 2). Variation in trematode loads was not associated with variation in mass of any organ. Interpretation of the effects of nematodes on organs varied according to whether uninfected individuals were excluded from analysis. When uninfected individuals were included, greater nematode loads were associated with lower spleen, higher caecum, lower large intestine, and lower heart masses. When uninfected individuals were excluded, associations of nematode loads with caecum and large intestine masses remained, the association with spleen mass was no longer significant, and greater nematode loads were associated with higher crop mass (Table 2). The variation in organ masses explained by helminth load was calculated using the Type III mean squares (MS). For example, total MS for spleens was 2.43, of which $19 \%$ was attributable to the combined effects of helminths. The $R^{2}$ value for spleens was 0.19 (Table 2), so $4 \%$ 
Fig. 1. Associations between loads of each helminth group, cestodes, trematodes, and nematodes, and variation in spleen mass. Sample sizes are the same in each case but graphs appear to differ because of variation in the number of overlapping points.
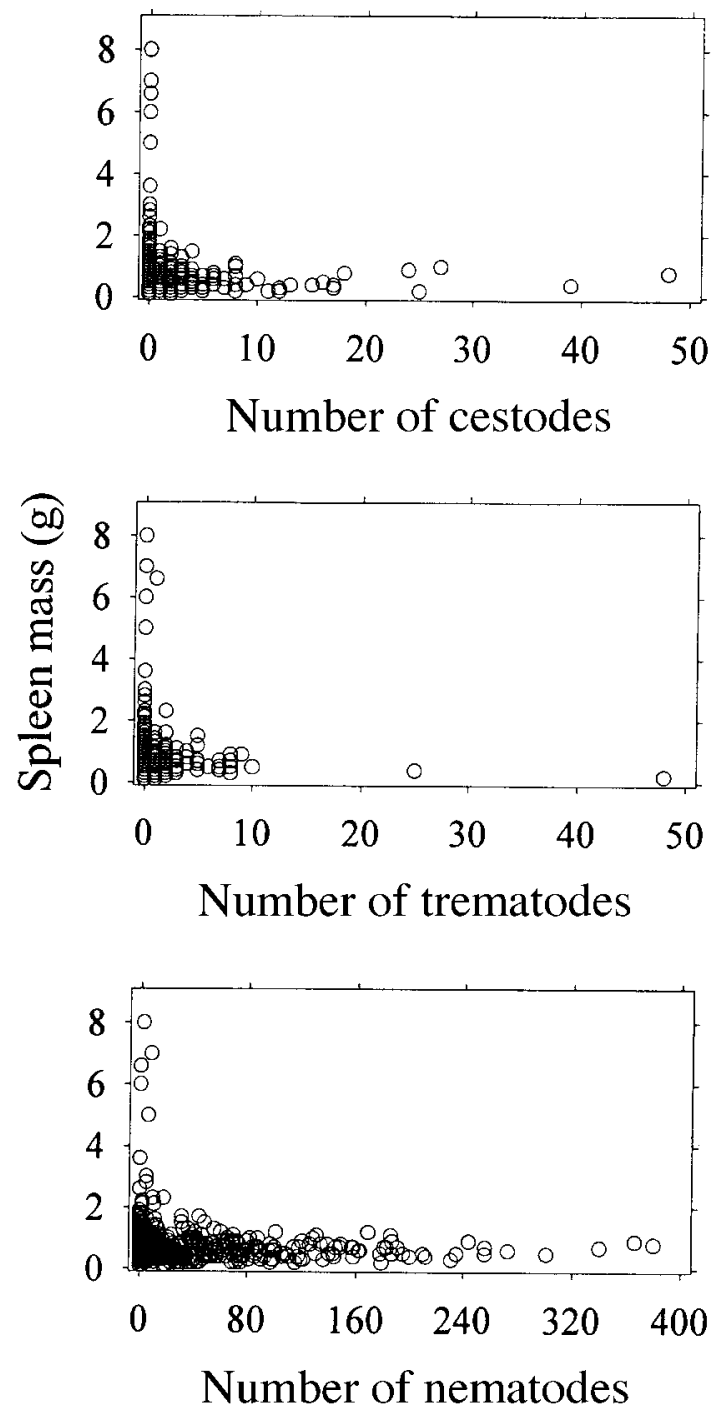

$(0.19 \times 0.19)$ of spleen mass was explained by helminths. Comparable values for the caecum, small intestine, large intestine, pancreas, heart, and crop were $6,1,2,2,2$, and $0.4 \%$, respectively.

The second MANCOVA tested for synergism among helminth groups in causing variation in organ masses. As we found with the first MANCOVA, sample, host age, host sex, and host size were associated with variation in organ masses (Table 3). ANCOVAS indicated associations between sample and all organs, between sex and all organs, and between age and crop mass only. Individuals with multiple helminth infections had lighter spleens (Table 3). ANCOVAs for this second analysis also revealed that number of groups explained $3,0.5,0.2,0.8,1,0.1$, and $0.2 \%$ of variation in spleen, caecum, small intestine, large intestine, pancreas, heart, and crop mass, respectively.

The third MANCOVA revealed that helminth loads varied especially among samples (Table 4; this variation is being analyzed separately by M. Forbes, R.T. Alisaiskas, J.D. McLaughlin, and K.M. Cuddington, in preparation). Sex, age, and size did not explain significant variation in helminth load. Helminth loads were greater in individuals with lower spleen (unless uninfected individuals were excluded), higher caecum, and lower heart masses. Both cestode and nematode loads were greater in individuals with lighter spleens but only when uninfected individuals were included. Greater nematode loads were associated with higher caecum, lower large intestine, and lower heart masses, regardless of whether or not uninfected individuals were included. Variation in cestode load, explained by variation in spleen, caecum, small intestine, large intestine, pancreas, heart, and crop masses, was $5,2,2,1,3,2$, and $0 \%$, respectively. Equivalent figures for variation in trematode load were $3,0,0.1,2,1,1$, and $2 \%$, and in nematode load were $4,5,0.2,3,2,4$, and $1 \%$, respectively.

The fourth analysis was a simple ANCOVA. Twenty percent of the variation in number of groups was explained by the four covariates and the seven organ masses. Sample $(F=$ $3.9, P<0.0001)$ and age $(F=4.8, P=0.03)$ were significant covariates. As was revealed by the second MANCOVA, more helminth groups were associated with lighter spleens $(F=9.3, P=0.002)$.

\section{Discussion}

We found evidence that helminth loads of lesser snow geese were associated with lower spleen, lower caecum, lower large intestine, lower heart, and higher crop masses. However, helminth associations explained only a small amount of variation in organ masses. Moreover, of relationships between organ masses and helminth loads, those for the spleen were not consistently the strongest. Thus, we did not uncover strong support for the spleen as a currency of anti-helminth investment in wild geese. Our large sample sizes should have allowed us to detect even weak associations and may explain the unexpected associations with some organs. Again, the small variation in organ masses that was explained by helminth load argues against making too strong a case for any of the latter associations.

One possible explanation for our largely negative results is that timing of spleen investment and helminth proliferation are not concurrent. However, splenomegaly is observed when parasites reach maximum infection intensity (Fallis et al. 1951; Vincent and Ash 1978; Ali and Behnke 1985; Garside et al. 1989; Watkins et al. 1991). Moreover, helminth infections and splenomegaly can both persist for several weeks (Ali and Behnke 1985; Garside et al. 1989). Because geese were collected over 4 months, it is likely that we encountered some individuals with maximal infections. Nonetheless, maximal infections were not associated with splenomegaly, suggesting that helminth infection is relatively benign and therefore does not elicit a strong immune response. If anything, our results provide weak support for the hypothesis that insufficient immune investment resulted in greater nematode loads. Possibly, individuals with heavy helminth loads reach an infection threshold at which time they make short-term bursts in immune investment that purge most helminths. If a large spleen persists after these purges, this could explain the patterns in Fig. 1. 
Table 2. $F$ values associated with Wilks' $\lambda$ from a MANCOVA and from separate ANCOVAs of seven organ masses versus covariates and each helminth group.

\begin{tabular}{|c|c|c|c|c|c|c|c|c|}
\hline \multirow{2}{*}{$\begin{array}{l}\text { Covariate or } \\
\text { explanatory } \\
\text { variable }\end{array}$} & \multirow[b]{2}{*}{$\mathrm{MANCOVA}^{a}$} & \multicolumn{7}{|l|}{ Organ $^{b}$} \\
\hline & & $\begin{array}{l}\text { Spleen } \\
(0.19,0.19)\end{array}$ & $\begin{array}{l}\text { Caecum } \\
(0.41,0.45)\end{array}$ & $\begin{array}{l}\text { Small intestine } \\
(0.26,0.31)\end{array}$ & $\begin{array}{l}\text { Large intestine } \\
(0.26,0.31)\end{array}$ & $\begin{array}{l}\text { Pancreas } \\
(0.19,0.19)\end{array}$ & $\begin{array}{l}\text { Heart } \\
(0.43,0.45)\end{array}$ & $\begin{array}{l}\text { Crop } \\
(0.33,0.37)\end{array}$ \\
\hline Sample & $8.7 * * *$ & $3.6^{* * *}$ & $16.8 * * *$ & $27.9 * * *$ & $4.9 * * *$ & $4.1 * * *$ & $9.0 * * *$ & $7.0 * * *$ \\
\hline Age & $2.1 *$ & 0.4 & 1.3 & 2.4 & 2.3 & 0.6 & 0.4 & $6.9 * *$ \\
\hline Sex & $34.8 * * *$ & $4.1 *$ & $4.8^{*}$ & $9.5 * *$ & $35.4 * * *$ & $16.6 * * *$ & $118.8 * * *$ & $65.5 * * *$ \\
\hline Trematodes & 0.7 & 1.6 & 0.4 & 0 & 1.1 & 0 & 1.2 & 0.3 \\
\hline Nematodes & $3.7 * * *$ & $4.2^{*}$ & $5.6^{*}$ & 0.3 & $4.9 *$ & 2.4 & $7.3 * * *$ & 2 \\
\hline \multicolumn{9}{|c|}{ With uninfected individuals excluded } \\
\hline Sample & $7.7 * * *$ & $2.9 * * *$ & $15.3 * * *$ & $20.8 * * *$ & $5.7 * * *$ & $3.5 * * *$ & $8.0 * * *$ & $7.2 * * *$ \\
\hline Age & 1 & 0.5 & 0.9 & 0.9 & 0.8 & 0.5 & 0.8 & 2 \\
\hline Nematodes & $4.4 * * *$ & 3.4 & $7.7 * *$ & 0 & $6.6^{*}$ & 2.7 & $4.1^{*}$ & $6.6^{*}$ \\
\hline
\end{tabular}

${ }^{a}$ All variables had $1 \mathrm{df}$ except sample, which had $26 \mathrm{df}$. *, $P<0.05 ; * *, P<0.01 ; * * * P,<0.001$.

${ }^{b}$ Numbers in parentheses are ANCOVA $R^{2}$ values with uninfected individuals included and excluded.

Table 3. $F$ values from a MANCOVA and separate ANCOVAs of seven organ masses versus sample, age, sex, size, and number of groups ( $N=164$ individuals with zero helminth groups, $N=336$ with one group, and $N=244$ with more than one group).

\begin{tabular}{|c|c|c|c|c|c|c|c|c|}
\hline $\begin{array}{l}\text { Covariate or } \\
\text { explanatory variable }\end{array}$ & MANCOVA $^{a}$ & \multicolumn{7}{|l|}{ Organ $^{b}$} \\
\hline Age & $2.6^{*}$ & 0.3 & 1.6 & 2.4 & 2.5 & 0.8 & 0.5 & $7.6^{* *}$ \\
\hline Sex & $36.6 * * *$ & $4.5^{*}$ & $4.0 *$ & $9.4 * *$ & $38.9 * * *$ & $17.1 * * *$ & $119.9 * * *$ & $66.8 * * *$ \\
\hline Size & $38.4 * * *$ & $32.1 * * *$ & $22.5 * * *$ & $32.8 * * *$ & $40.1 * * *$ & $15.2 * * *$ & $67.8 * * *$ & $102.1 * * *$ \\
\hline
\end{tabular}

${ }^{a}$ All variables had $1 \mathrm{df}$ except sample, which had $26 \mathrm{df}$, and number of groups, which had $2 \mathrm{df} . *, P<0.05 ; * *, P<0.01 ; * * *, P<0.001$.

${ }^{b}$ Numbers in parentheses are ANCOVA $R^{2}$ values.

Many observational studies fail to detect effects of parasites (e.g., Bennett et al. 1988, 1993). One possible reason is that few individuals in wild populations carry heavy parasite loads, and those that do may die before being sampled. If significant mortality and variation in organ masses occur only above some threshold parasite load, this may explain the relatively weak associations with organ masses that we observed. However, we found little evidence of organ response even in the most heavily infected individuals, so mortality is unlikely to be the cause of our largely negative results. There are other possible covariates that may have prevented us from observing organ-helminth associations. For example, we could not precisely control for previous exposure history of our geese. Age is a partial surrogate for previous exposure, but it was not important in explaining variation in helminth load. Moreover, previous exposure is not a guarantee of immunity to helminths (Wakelin and Apanius 1997). Additional covariates in the schema of Folstad and Karter (1992) include hormones and secondary sexual character development. We lack data to enable us to consider these elements. Another possibility is that organ masses in our geese may have been more closely related to investment against other, unmeasured parasite taxa (even parasite assays that involve exhaustive effort are never complete; Cox 1989; Weatherhead et al. 1993). In any case, we cannot dismiss all of these possibilities in explaining our results. However, if there were important associations between helminth load and organ masses, our large samples should have revealed them, even had variation been introduced from other covariates.

A possible explanation for the observed association of lighter spleens with greater helminth loads is that the helminths may have depressed the immune systems of our geese for their own benefit. Such immunity modulation has been documented in various host-parasite systems, including those involving helminths (Garside et al. 1989; Beckage 1991; Eckert 1991; Maizels et al. 1993), and we could not rule out this possibility. However, John's (1995) results suggest that immunity modulation is not a common aspect of avian-helminth systems. A related possibility is that helminths carried by our geese are particularly effective at avoiding immune defenses (Eckert 1991). In this case, it may not pay hosts to invest substantially in defense (John 1995; Yan et al. 1997).

Immune response probably evolved to eliminate parasites 
Table 4. $F$ values from a MANCOVA to test whether helminth load is a consequence of investment in organ mass, when covariates are controlled for.

\begin{tabular}{|c|c|c|c|c|}
\hline \multirow[b]{2}{*}{$\begin{array}{l}\text { Covariate or } \\
\text { explanatory variable }\end{array}$} & \multirow[b]{2}{*}{ MANCOVA $^{a}$} & \multicolumn{3}{|c|}{ Helminth group $^{b}$} \\
\hline & & $\begin{array}{l}\text { Cestodes } \\
(0.26,0.26)\end{array}$ & $\begin{array}{l}\text { Trematodes } \\
(0.18,0.26)\end{array}$ & $\begin{array}{l}\text { Nematodes } \\
(0.27,0.25)\end{array}$ \\
\hline \multicolumn{5}{|c|}{ With uninfected individuals included } \\
\hline Sample & $5.8 * * *$ & $7.3 * * *$ & $4.9 * * *$ & $5.5 * * *$ \\
\hline Age & 1.6 & 0.3 & 2.1 & 3 \\
\hline Sex & $2.8^{*}$ & 3 & 1.7 & 3.7 \\
\hline Size & 0.4 & 0.3 & 1 & 0.1 \\
\hline Spleen & $3.5^{*}$ & $4.6^{*}$ & 2.3 & $5.0^{*}$ \\
\hline Caecum & $2.9^{*}$ & 2 & 0 & $7.2 * *$ \\
\hline Small intestine & 0.6 & 1.6 & 0.1 & 0.3 \\
\hline Large intestine & 2.1 & 0.9 & 1.7 & $3.9^{*}$ \\
\hline Pancreas & 1.5 & 2.8 & 0 & 2.2 \\
\hline Heart & $3.3^{*}$ & 1.9 & 0.9 & $5.8^{*}$ \\
\hline Crop & 0.8 & 0 & 1.2 & 0.9 \\
\hline \multicolumn{5}{|c|}{ With uninfected individuals excluded } \\
\hline Sample & $5.2 * * *$ & $5.6^{* * *}$ & $6.0 * * *$ & $4.7 * * *$ \\
\hline Age & 0.4 & 0 & 0.6 & 0.4 \\
\hline Sex & 2.6 & 2.4 & 2.6 & 2.9 \\
\hline Size & 0.4 & 0.2 & 0.9 & 0.3 \\
\hline Spleen & 2.2 & 2.5 & 2.3 & 1.8 \\
\hline Caecum & $3.5^{*}$ & 1.1 & 0.1 & $9.3 * *$ \\
\hline Small intestine & 0.6 & 1.7 & 0.2 & 0 \\
\hline Large intestine & 2 & 1 & 0 & $4.9^{*}$ \\
\hline Pancreas & 1.9 & 3.6 & 0 & 1.9 \\
\hline Heart & $2.9^{*}$ & 3.6 & 0.9 & $4.2 *$ \\
\hline Crop & 2.2 & 0.1 & 1.1 & $5.6^{*}$ \\
\hline
\end{tabular}

only when the costs of immunity are less than those imposed by parasites. Aside from this, there are trade-offs between immunity and competing demands, such as migration and reproduction. Energetic demands vary seasonally, and our results clearly indicated that sampling intervals were associated with substantial temporal variation in helminth loads and organ sizes. With respect to the trade-off between the benefits of helminth elimination and the costs of immunity, John (1995) found that nematodes were the only helminth associated with larger spleens in an interspecific analysis, and he noted that larval forms of these parasites can cause costly tissue damage in various parts of the host (e.g., Read and Skorping 1995). Similarly, we found that nematodes were most often associated with variation in organ masses. In contrast, parasitic stages of cestodes remain in the gut and cause minimal tissue damage. Trematodes may also cause tissue damage, but their infections may be more difficult to detect in some host species (John 1995). However, goose trematodes are relatively easy to detect. At any rate, a more focused prediction is that parasites that cause greater pathology should elicit a greater immune response, as is suggested by the numerous organ mass - nematode associations we detected. Elsewhere (R.T. Alisauskas, D. Shutler, and J.D. McLaughlin, in preparation), we test for another aspect of pathology: the nutritional condition of the host. Condition may be reduced because of nutrient loss to parasites or from an increase in investment to repair tissue damage.
The lack of phenotypic immune response by geese (i.e., smaller spleens in infected individuals) suggests that their helminths cause no significant pathology, and we should therefore detect minimal effects on condition. If, however, nematodes are the most pathological helminth group, they should have the greatest influence on condition.

Our results depended on short-term responses by geese, whereas comparative analyses test evolutionary responses to parasites. Hence, although our results suggest weak associations with helminths, this does not necessarily imply that the effects of helminths are insignificant over evolutionary time. In contrast to the results of observational studies, there are numerous experimental demonstrations of the costs of parasites (e.g., Connors and Nickol 1991; Booth et al. 1993; Richner et al. 1993, 1995; Norris et al. 1994), as predicted from theory (Anderson and May 1979; Keymer and Read 1991). Moreover, comparative analyses by John (1994b, 1995) and co-workers (Harvey et al. 1991) have shown significant positive relations between helminths and spleen mass, and this is also evidence of a cost of parasitism. Beause helminths are considered relatively benign parasites (Rausch 1983), both comparative and experimental approaches may be necessary to reveal their effects.

Our results provide weak support for the hypothesis that variation in goose spleen size affects susceptibility to helminth infection. We focused on the spleen, but it is only one potential currency of antiparasite investment. Additional 
immune-system organs include the bursa of Fabricius (usually present in young birds only), the thymus, and Peyer's patch (Glick 1986). These organs can also vary in size in response to some parasitic infections (e.g., Ould and Welch 1980; Glick 1983; M. Rau, personal communication). Moreover, immune response can also be measured from levels of immunoglobulins, leucocytes, and lymphocytes, all of which were associated with variation in infection intensities (e.g., Bubenik and Brownlee 1987; Gustafsson et al. 1994; Dufva and Allander 1995; Saino et al. 1995; Zuk 1996). Which aspect of immune response is the best intraspecific currency of antihelminth investment remains to be seen. In addition, we need to investigate further which currencies are best for helminths and which for non-helminths, and how well these currencies relate to parasite virulence.

\section{Acknowledgments}

For multifarious assistance we thank Andrew Read, Adele Mullie, Dave Ankney, Kit Muma, Dorothy Riley, and Gloria Dobush. For laboratory assistance we thank Janet Rokas, Blair Cribb, and Spiros Fengos. Financial assistance was provided by the Natural Sciences and Engineering Research Council of Canada through operating grant A6979 to J.D. McLaughlin. Important insights were provided by Andrew Read, Manfred Rau, Jerzy Behnke, and Robert G. Clark. All geese were collected under scientific collection permits from state, provincial, and federal jurisdictions in which our research was done.

\section{References}

Alexander, J., and Stimson, W.H. 1988. Sex hormones and the course of parasitic infection. Parasitol. Today, 4: 189-193.

Ali, N.M.H., and Behnke, J.M. 1985. Observations on the gross changes in the secondary lymphoid organs of mice infected with Nematospiroides dubius. J. Helminthol. 59: 167-174.

Alisauskas, R.T. 1988. Nutrient reserves of Lesser Snow Geese during winter and spring migration. Ph.D. thesis, University of Western Ontario, London.

Alisauskas, R.T., and Ankney, C.D. 1992. Spring habitat use and diets of midcontinental adult lesser snow geese. J. Wildl. Manage. 56: $43-54$.

Alisauskas, R.T., and Hobson, K.A. 1993. Determination of lesser snow goose diets and winter distribution using stable isotope analysis. J. Wildl. Manage. 57: 49-54.

Alisauskas, R.T., Ankney, C.D., and Klaas, E.E. 1988. Winter diets and nutrition of midcontinental lesser snow geese. J. Wildl. Manage. 52: 403-414.

Anderson, R.M., and May, R.M. 1979. Population biology of infectious diseases. Part I. Nature (Lond.), 280: 361-367.

Barnard, C.J., Behnke, J.M., and Sewell, J. 1996. Social status and resistance to disease in house mice (Mus musculus): statusrelated modulation of hormonal responses in relation to immunity costs in different social and physical environments. Ethology, 102: 63-84.

Batt, R.A.L. 1980. Influences on animal growth and development. Edward Arnold (Publishers) Ltd., London.

Beckage, N.E. 1991. Host-parasite hormonal relationships: a common theme? Exp. Parasitol. 72: 332-338.

Bennett, G.F., Campbell, A.G., and Cameron, M. 1974. Hematozoa of passeriform birds from insular Newfoundland. Can. J. Zool. 52: 765-772.
Bennett, G.F., Caines, J.R., and Bishop, M.A. 1988. Influence of blood parasites on the body mass of passeriform birds. J. Wildl. Dis. 24: 339-343.

Bennett, G.F., Peirce, M.A., and Ashford, R.W. 1993. Avian Haematozoa: mortality and pathogenicity. J. Nat. Hist. 26: 993-1001.

Booth, D.T., Clayton, D.H., and Block, B.A. 1993. Experimental demonstration of the energetic cost of parasitism in free-ranging hosts. Proc. R. Soc. Lond. B Biol. Sci. 253: 125-129.

Brown, C.R., Brown, M.B., and Rannala, B. 1995. Ectoparasites reduce long-term survival of their avian host. Proc. R. Soc. Lond. B Biol. Sci. 263: 313-319.

Bubenik, G.A., and Brownlee, L. 1987. Assessing health of male white-tailed deer by white blood cell counts. J. Wildl. Manage. 51: $57-58$.

Bundy, D.A.P. 1988. Gender-dependent patterns of infection and disease. Parasitol. Today, 4: 186-189.

Connors, V.A., and Nickol, B.B. 1991. Effects of Plagiorhynchus cylindraceus (Acanthocephala) on the energy metabolism of adult starlings, Sturnus vulgaris. Parasitology, 103: 395-402.

Cox, F.E.G. 1989. Parasites and sexual selection. Nature (Lond.), 341: 289.

Crompton, D.W.T. 1991. Nutritional interactions between hosts and parasites. In Parasite-host associations: coexistence or conflict? Edited by C.A. Toft, A. Aeschlimann, and L. Bolis. Oxford University Press, Oxford. pp. 228-257.

Drobney, R.D., Train, C.T., and Fredrickson, L.H. 1983. Dynamics of the platyhelminth fauna of wood ducks in relation to food habits and reproductive state. J. Parasitol. 69: 375-380.

Dufva, R., and Allander, K. 1995. Intraspecific variation in plumage coloration reflects immune response in Great Tit (Parus major) males. Funct. Ecol. 9: 785-789.

Eckert, J. 1991. Interactions between cestodes and their vertebrate hosts. Parasite-host associations: coexistence or conflict? In Parasite-host associations: coexistence or conflict? Edited by C.A. Toft, A. Aeschlimann, and L. Bolis. Oxford University Press, Oxford. pp. 201-227.

Fallis, A.M., Davies, D.M., and Vickers, M.A. 1951. Life history of Leucocytozoon simondi Mathis and Leger in natural and experimental infections and blood changes produced in the avian host. Can. J. Zool. 26: 305-328.

Folstad, I., and Karter, A.J. 1992. Parasites, bright males, and the immunocompetence handicap. Am. Nat. 139: 603-622.

Garside, P., Behnke J.M., and Rose, R.A. 1989. The immune response of male DSN hamsters to a primary infection with Ancylostoma ceylanicum. J. Helminthol. 63: 251-260.

Giacomo, R., Stefania, P., Ennio, T., Giorgina, V.C., Giovanni, B., and Giacomo, R. 1997. Mortality in black siskins (Carduelis atrata) with systemic coccidiosis. J. Wildl. Dis. 33: 152-157.

Glick, B. 1983. Bursa of Fabricius. In Avian biology. Vol. 7. Edited by D.S. Farner, J.R. King, and K.C. Parkes. Academic Press, New York. pp. 443-500.

Glick, B. 1986. Immunophysiology. In Avian physiology. Edited by P.D. Sturkie. Springer-Verlag, New York. pp. 87-101.

Goater, C.P., Semlitsch, R.D., and Bernasconi, M.V. 1993. Effects of body size and parasite infection on the locomotory performance of juvenile toads, Bufo bufo. Oikos, 66: 129-136.

Gustafsson, L., Nordling, D., Anderson, M.S., Sheldon, B.C., and Qvärnstrom, A. 1994. Infectious diseases, reproductive effort and the cost of reproduction in birds. Philos. Trans. R. Soc. Lond. B Biol. Sci. 346: 323-331.

Harvey, P.H., Read, A.F., John, J.L., Gregory, R.D., and Keymer, A.E. 1991. An evolutionary perspective: using the comparative method. In Parasite-host associations: coexistence or conflict? 
Edited by C.A. Toft, A. Aeschlimann, and L. Bolis. Oxford University Press, Oxford. pp. 344-355.

Hatcher, L., and Stepanski, E.J. 1994. A step-by-step approach to using the SAS system for univariate and multivariate statistics. SAS Institute Inc., Cary, N.C.

Holm, S. 1979. A simple sequentially rejective multiple test procedure. Scand. J. Stat. 6: 65-70.

Holmes, J.C., and Zohar, S. 1990. Pathology and host behaviour. In Parasitism and host behaviour. Edited by C.J. Barnard and J.M. Behnke. Taylor and Francis, London. pp. 34-64.

Howard, R.D., and Minchella, D.J. 1990. Parasitism and mate competition. Oikos, 58: 120-122.

Hudson, P.J., Dobson, A.P., and Newborn, D. 1992. Do parasites make prey vulnerable to predation? Red grouse and parasites. J. Anim. Ecol. 61: 681-692.

John, J.L. 1994a. The avian spleen: a neglected organ. Q. Rev. Biol. 69: 327-351.

John, J.L. 1994b. Nematodes and the spleen: an immunological relationship. Experientia (Basel), 50: 15-22.

John, J.L. 1995. Parasites and the avian spleen: helminths. Biol. J. Linn. Soc. 54: 86-106.

Kehoe, F.P., and Ankney, C.D. 1985. Variation in digestive organ size among five species of diving ducks (Aythya spp.). Can. J. Zool. 63: 2339-2342.

Keymer, A.E., and Read, A.F. 1991. Behavioural ecology: the impact of parasitism. In Parasite-host associations: coexistence or conflict? Edited by C.A. Toft, A. Aeschlimann, and L. Bolis. Oxford University Press, Oxford. pp. 37-61.

Konarzewski, M., and Diamond, J. 1995. Evolution of basal metabolic rate and organ masses in laboratory mice. Evolution, 49: 1239-1248.

Maizels, R.M., Bundy, D.A.P., Selkirk, M.E., Smith, D.F., and Anderson, R.M. 1993. Immunological modulation and evasion by helminth parasites in human populations. Nature (Lond.), 365: 797-805.

McCurdy, D.G., Shutler, D., Mullie, A., and Forbes, M.R.L. 1998. Sex-biased parasitism of avian hosts: relations to blood parasite taxon and mating system. Oikos, 82: 303-312.

Møller, A.P., Allander, K., and Dufva, R. 1990. Fitness effects of parasites on passerine birds: a review. In Population biology of passerine birds: an integrated approach. Edited by J. Blondel, A. Gosler, J.-D. Lebreton, and R.H. McCleery. Springer-Verlag, New York. pp. 269-281.

Norris, K., Anwar, M., and Read, A.F. 1994. Reproductive effort influences the prevalence of haematozoan parasites in great tits. J. Anim. Ecol. 63: 601-610.

Ould, P., and Welch, H.E. 1980. The effect of stress on the parasitism of mallard ducklings by Echinuria uncinata (Nematoda: Spirurida). Can. J. Zool. 58: 228-234.

Poulin, R. 1996. Sexual inequalities in helminth infections: a cost of being a male? Am. Nat. 147: 287-295.

Rausch, R.L. 1983. The biology of avian parasites: helminths. In Avian biology. Vol. 7. Edited by D.S. Farner, J.R. King, and K.C. Parkes. Academic Press, New York. pp. 367-442.

Read, A.F., and Skorping, A. 1995. The evolution of tissue migration by parasitic nematode larvae. Parasitology, 111: 359-371.

Reznick, D. 1985. Costs of reproduction: an evaluation of the empirical evidence. Oikos, 44: 257-267.

Rice, W.R. 1989. Analyzing tables of statistical tests. Evolution, 43: $223-225$.

Richner, H., Oppliger, A., and Christe, P. 1993. Effect of an ectoparasite on reproduction in great tits. J. Anim. Ecol. 62: 703-710.
Richner, H.A., Christe, P., and Oppliger, A. 1995. Paternal investment affects prevalence of malaria. Proc. Natl. Acad. Sci. U.S.A. 92: 1192-1194.

Saino, N., Møller, A.P., and Bolzern, A.M. 1995. Testosterone effects on the immune system and parasite infestations in the barn swallow (Hirundo rustica): an experimental test of the immunocompetence hypothesis. Behav. Ecol. 6: 397-404.

SAS Institute Inc. 1990. SAS/STAT user's guide, version 6, 4th ed. SAS Institute Inc., Cary, N.C.

Schalk, G., and Forbes, M.R. 1997. Male biases in parasitism of mammals: effects of study type, host age, and parasite taxon. Oikos, 78: 67-74.

Schall, J.J., Bennett, A.F., and Putnam, R.W. 1982. Lizards infected with malaria: physiological and behavioral consequences. Science (Washington, D.C.), 217: 1057-1059.

Seebeck, R.M., Springell, P.H., and O'Kelly, J.C. 1971. Alterations in host metabolism by the specific and anorectic effects of the cattle tick (Boophilus microplus). I. Food intake and body weight growth. Aust. J. Biol. Sci. 24: 373-380.

Shutler, D., Bennett, G.F., and Mullie, A. 1995. Sex proportions of Haemoproteus blood parasites and local mate competition. Proc. Natl. Acad. Sci. U.S.A. 92: 6748-6752.

Shutler, D., Ankney, C.D., and Dennis, D.G. 1996. Could the blood parasite Leucocytozoon deter mallard range expansion? J. Wildl. Manage. 60: 569-580.

Smith, F.V., Barnard, C.J., and Behnke, J.M. 1996. Social odours, hormone modulation and resistance to disease in male laboratory mice, Mus musculus. Anim. Behav. 52: 141-153.

Spalding, M.G., Smith, J.P., and Forrester, D.J. 1994. Natural and experimental infections of Eustrongylides ignotus: effect on growth and survival of nestling wading birds. Auk, 111: 328336.

Temple, S.A. 1987. Do predators always capture substandard individuals disproportionately from prey populations? Ecology, 68: 669-674.

Thompson, S.N. 1990. Physiological alterations during parasitsim and their effects on host behaviour. In Parasitism and host behaviour. Edited by C.J. Barnard and J.M. Behnke. Taylor and Francis, London. pp. 64-94.

Vincent, A.L., and Ash, L.R. 1978. Splenomegaly in jirds (Meriones unguiculatus) infected with Brugia malayi (Nematoda: Filarioidea) and related species. Am. J. Trop. Med. Hyg. 27: 514-520.

Wakelin, D., and Apanius, V. 1997. Immune defence: genetic control. In Host-parasite evolution: general principles and avian models. Edited by D.H. Clayton and J. Moore. Oxford University Press, Oxford. pp. 30-58.

Watkins, R.A., Moshier, S.E., O’Dell, W.D., and Pinter, A.J. 1991. Splenomegaly and reticulocytosis caused by Babesia microti infections in natural populations of the montane vole, Microtus montani. J. Protozool. 38: 573-576.

Weatherhead, P.J., and Bennett, G.F. 1991. Ecology of Red-winged Blackbird parasitism by haematozoa. Can. J. Zool. 69: 2352 2359.

Weatherhead, P.J., and Bennett, G.F. 1992. Ecology of parasitism of Brown-headed Cowbirds by haematozoa. Can. J. Zool. 70: 1-7.

Weatherhead, P.J., Metz, K.J., Bennett, G.F., and Irwin, R.E. 1993. Parasite faunas, testosterone and secondary sexual traits in male red-winged blackbirds. Behav. Ecol. Sociobiol. 33: 13-23.

Yan, G., Severson, D.W., and Christensen, B.M. 1997. Costs and benefits of mosquito refractoriness to malaria parasites: implications for genetic variablility of mosquitoes and genetic control of malaria. Evolution, 51: 441-450. 
Zuk, M. 1990. Reproductive strategies and disease susceptibility: an evolutionary viewpoint. Parasitol. Today, 6: 231-233.
Zuk, M. 1996. Disease, endocrine-immune interactions, and sexual selection. Ecology, 77: 1037-1042. 